\title{
The Opportunities of the Foreigner Investments in Kosovo
}

\author{
Shpresa Bajrami PhD.c
}

\begin{abstract}
This paper discuss about the investing opportunities in Kosovo. Kosovo as a new country in Europe possess many opportunities regarding the foreigner investments. Foreign companies as well as business people see this country as a good market to invest and every year we get new foreigner investor raising interest toward this matter. Firstly, we will discuss the advantage of having the youngest generation in Europe as a good opportunity to invest. Secondly, we will see the impact of the high unemployment rate as cheap labor force. Thirdly, we will talk about the geographic location that Kosovo possess as a good opportunity to invest because it is in the middle of the Europe. At the end, it will be presented the obstacles of investing in Kosovo as in the rule of law and its lack on political stability and its interference on the investments.
\end{abstract}

Keywords: Foreigner investments, new generation, unemployment rate, cheap labors, geographic location, obstacles, rule of law, political stability.

DOI: $10.7176 /$ RJFA/10-4-09

\section{Introduction}

The global economy has significantly grown with the furthering of the process of globalization which has resulted in a global financial, industrial and business system.

Liberalization of trade, by implementing free-market policies and lowering trade barriers together with the creation of an international framework that serves as a promoting and safeguarding system, primarily seen in the international agreements on trade and international institutions, have led to rapid growth in trade and investment. Economic opening of national borders has unlocked the potential for further growth by increasing the productive capacities and opportunities for investments.

One of these emerging markets is the Western Balkan region, whose countries after the breakdown of communist rule started their transition process with the goal of becoming free-market democracies that would join the European Union as full members.

Unlike the countries from Eastern Europe, this region due to the negative developments right after the system change, lagged behind and lost valuable time and resources. Despite this, the countries of the Western Balkan region managed to stabilize macro economically and implement the major part of necessary reforms.

Kosovo is a country that offers many opportunities for investment. It has a good strategic position, is a country in the euro area, it has the youngest population in Europe and has low taxes and cost-efficient workforce. The banking system is one of the most stable in the region, and the privatization of public enterprises is in progress which brings great opportunities for foreign investors. Today, Kosovo has more than 3000 foreign companies and mixed ownership. This investment is spread across a wide range of business sectors, as well as investments in publicly owned assets sold by the government as part of the privatization program.

In addition, Kosovo enjoys finally inclusion in the customs free access to the European Union and the United States through the EU. Autonomous trade preferences and generalized system of preferences allows all investors to be exported to EU and U.S., without any customs duty.

Economic growth and development also stem from the accumulation of physical capital (investment), human capital (labor) and technological advancement. However, the experience of countries that have grown fastest production indicates the importance of creating the necessary conditions are favorable for long term growth of income per capita, in other words, economic stability, institution building and structural reforms, etc. are apparatus very important for financial and technical assistance on long-term, to finance investments in physical and social infrastructure in Kosovo, which are crucial for attracting private investment.

In broad terms, the minimum prerequisite to the process of globalization takes root and be useful, a country must include the banking system lubricates economic process through inter-effective financing, liberal system, openness and democratic practices, strong private sector, motivated by profits moderate, alert citizens who assume the government in the fingers and a growing economy. (We take 2007 as limit year due to the consequences of the global financial crisis that followed in subsequent years)

\section{Labor market}

Kosovo has both the youngest population in Europe $-70 \%$ is younger than 35 years old, and the highest youth unemployment rates in Europe $-40 \%$ of the total number of unemployed. In 2008 the World Bank predicted that in the next five years another 200,000 young people would join Kosovo's labor force. ${ }^{1}$

\footnotetext{
1 Institute for advanced studies GAP, Jeton Mehmeti, Entrepreneurship and occupations of the future in Kosovo. http://www.gapmonitor.org/?id=17\&n=23\&language=en
} 


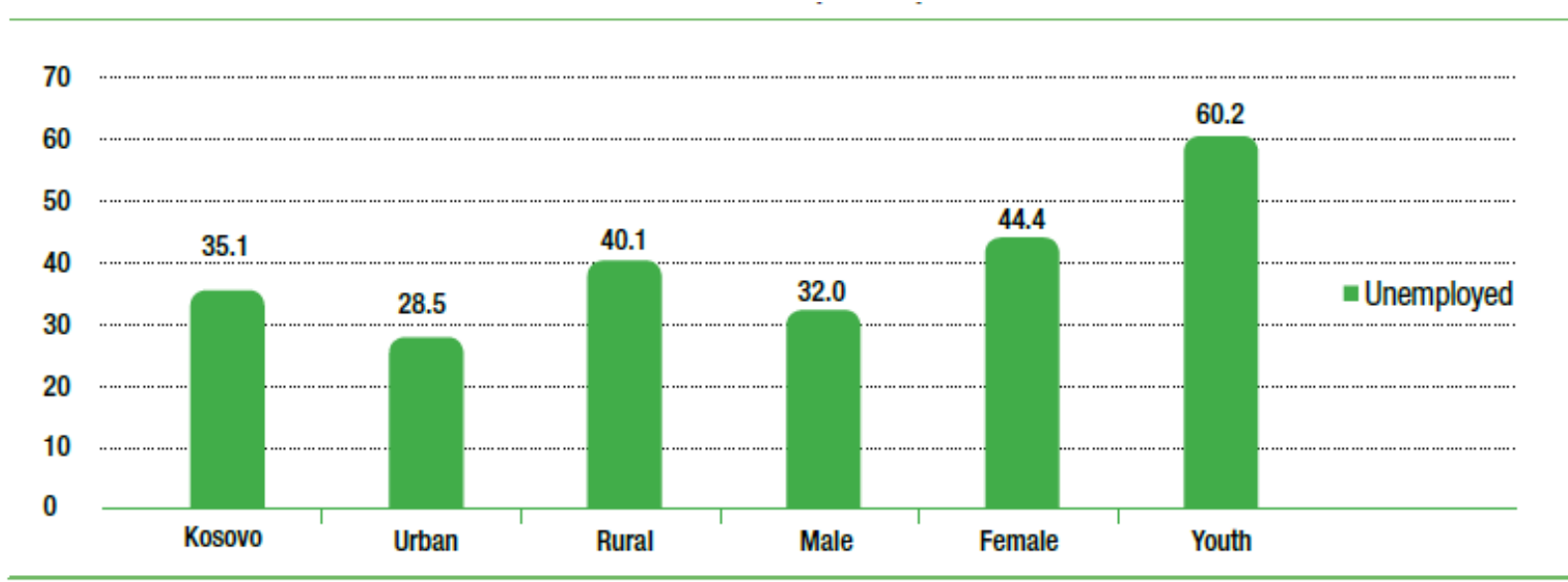

Scource : Unemployment Rate in Kosovo (\%), Labour Force Survey, January to June 2012
Kosovo Agency of Statistics

Kosovo by having high unemployment rate it has the high available of the work force with different skilled, multilingual and motivated labor with a strong entrepreneurial ideas and numbers knowledge of main European language. Therefore, hiring new employees is both time saving and simply when it comes to the procedures of recruitment. According Condition Index of the World Bank Kosovo can outperform many highly developed countries when it comes to the simplicity of hiring new employees.

Another advantage which is the main one is the cost of labor force. Kosovo has very cheap labor force with average monthly salary estimated at EUR 250 by World Bank in Kosovo it is the most competitive in the region. ${ }^{1}$ Table 1: Labor costs in the region (estimated by World Bank in Kosovo in 2009)

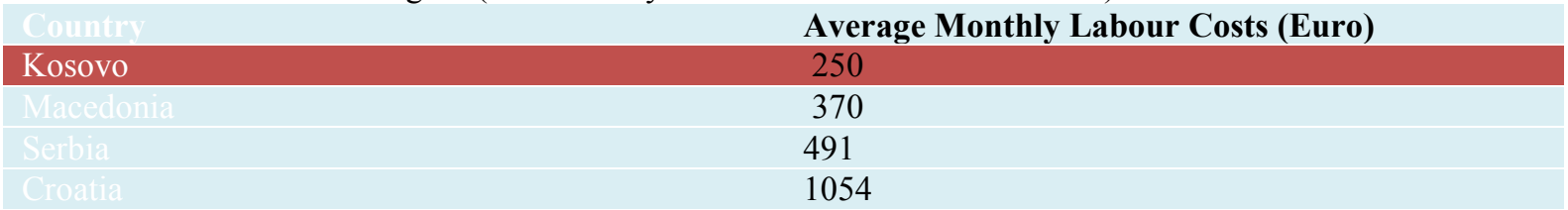

Regarding the income taxes are also low, which is $5 \%$ of the average gross salary. The only mandatory contributions are those for individual pensions savings accounts, financed by employer which is $5 \%$ and employee $5 \%$ as well.

Table 2: Contribution rates in selected countries (\% of salary)

\begin{tabular}{|l|l|l|l|}
\hline Country & Employee & Employer & Total \\
\hline Kosovo & 5 & 5 & 10 \\
\hline Czech Republic & 9.3 & 25.9 & 36.2 \\
\hline Slovakia & 9.9 & 26.3 & 47 \\
\hline Hungary & 13.5 & 33.5 & 47 \\
\hline Serbia & 17.9 & 17.9 & 35.8 \\
\hline Ausria & 14 & 22.5 & 36.6 \\
\hline Germany & 17.3 & 17.3 & 34.6 \\
\hline
\end{tabular}

Based on the table we can see that Kosovo has the lowest labor cost in the region by considering the average wage and taxes as well.

Therefore, this tells us that Kosovo is good country to invest by considering the labor force as a good advantage. $^{2}$

\section{Ease of Doing Business in Kosovo}

The analysis of the "ease of doing business in Kosovo" will include several factors determining Kosovo's business environment or the "doing business environment" as they are presented in the "Doing Business Report". The comparison and ranking between Kosovo and the other countries in the region gives an indication on the stability of the economy and the rule of law, elements which have key influence on determining the level of interest rates. The presented indicators affecting the overall business conditions have strong effect on the Banking sector, businesses currently operating in Kosovo as well as future potential investors. The business environment as defined by the "ease of doing business" is presented in the table below:

\footnotetext{
${ }^{1}$ Republic of Kosovo, ministry of trade and industry, investing in Kosovo 2009.

${ }^{2}$ Ibid.
} 
Table 3: Ease of Doing Business

\begin{tabular}{ll} 
& Ease of doing business \\
Country & Ranking 2014 \\
Macedonia & 25 \\
Montenegro & 44 \\
Average (Eastern Europe \& Central Asia) & 73 \\
Kosovo & $\mathbf{8 6}$ \\
Albania & 90 \\
Serbia & 93 \\
Bosnia and Herzegovina & 131 \\
\hline \hline
\end{tabular}

The ranking puts Kosovo in the middle part of the Table regarding the overall conditions for doing business compared with the Regional economies, ranked 86 out of 185 economies and thus influencing decisions of investors and stakeholders regarding cost of financing and interest rate level adjustments. ${ }^{1}$

Kosovo is among the countries that have eliminated minimum capital requirements in the past seven years. Moreover, Kosovo has made comprehensive changes to several areas of regulation that affect the protections of minority shareholders in related- party transactions. Three main points that Kosovo has made progress according to Doing business 2014, are: starting a business where Kosovo made it easier by creating a one-stop shop for incorporation, dealing with constructive permits is now easier by eliminating the requirements for validation of the main construction projects, eliminating fees for technical approvals from the municipality and reducing the building permit fee, and registering property where Kosovo made transferring property easier by introducing a new notary system and by combining procedures for drafting and legalizing sale and purchase agreements.

\section{The obstacles faced by investors}

Kosovo is a very young country that faces considerable political and social challenges. Tensions arising from the absence of unanimous international acceptance as an independent country have direct impact on the ability of the Central Bank of Kosovo (the "CBK") to fully execute its supervisory mandate. Of note is the inability of the CBK to conduct on site supervision in certain areas of Kosovo. Prior to independence, the legal framework was provided by the UNMIK regulations and, since independence in 2008, the Assembly has issued an important stream of legislation.

The rule of law in protecting investors (both domestic and foreign) influences investor's decisions regarding raising capital for new investments as well as creditor's decisions to disburse capital and to price that capital at appropriate level (level of interest rates) having in mind the economy's specific risks.

Strong regulations clearly define related-party transactions, promote clear and efficient disclosure requirements, require shareholder participation in major decisions of the company and set clear standards of accountability for company insiders.

The ranking of Kosovo's regulations regarding investor protection can be observed in the following table: Table 4: Investor protection

\begin{tabular}{ll} 
Country & Investor protection \\
Albania & Ranking 2013 \\
Macedonia & 17 \\
Montenegro & 19 \\
Average (Eastern Europe \& Central Asia) & 32 \\
Serbia & 62 \\
Kosovo & 82 \\
Bosnia & $\mathbf{1 0 0}$ \\
\hline \hline
\end{tabular}

Source: Doing Business report 2014

\footnotetext{
${ }^{1}$ World Bank, Doing Business 2014.
} 
The ranking on Investor protection reflect well-functioning courts and up-to-date procedural rules that give minority investors the means to prove their case and obtain a judgment within a reasonable time.

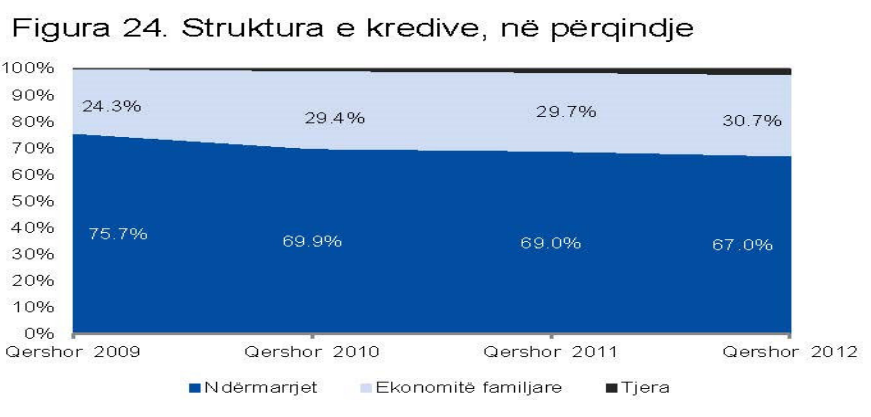

Burimi: BQK (2012)

Kosovo is ranked 100 out of 185 world economies in the world, and is 38 places below the Eastern Europe \& Central Asia average. So reforms to strengthen investor protections must move ahead on different fronts-such as through new or amended company laws or civil procedure rules which will increase the trust in the judicial system and rule of law and thus affect the overall environment for doing business including the Banking sector.

The informal economy (also referred to as the "informal sector", "grey economy" or the "shadow economy") although present in almost every country of the world, represents significant issue in developing countries and in countries with high unemployment rate like Kosovo. The informal economy hurts legal operated business and provides unfair competition to established companies operating in the formal sector.

The effects of the informal economy are systemic as they affect both the state budget by withholding taxes, fees and other contributions and to the labor rights and employment by not contributing social benefits and health and pension contributions.

Due to the existing data limitations and different methodologies for measuring the scope and characteristics, the level of the informal economy (as percent of GDP) is very hard to determine and correctly pinpoint. Different methods are used in different countries for measuring the size of informal economy, and each method has its own advantages and disadvantages and hence the difficulty arises when cross comparing these data.

There are only estimates and no objective data regarding the size of informal economy as an important component of Kosovo's economy. The experience of countries in transition and of other countries shows that the degree of economic formalization is positively related to the degree to which the economy is reformed and democratic and regulatory institutions are stabilized.

Informality of the economic sector undermines the trust between Companies and the financial institutions and limits the Companies approach to financing. On the other it increases the credit risks of the creditor regarding regular payments of the disbursed amount in the way that no credit analysis can be performed on official financial statements (even unaudited).

The foreign investments are also affected and discouraged by the unfair competition present on the market they are entering.

It is desirable to analyze the implementation and drawing encouraging informal sector in terms of the formal economy and to eliminate factors that influence in discouraging SMEs (Small and Medium Enterprises) to register employees, turnover and profit to certain authorities.

\section{Conclusion and recommendation}

Situated in South Eastern Europe, Kosovo's economy has become part of the region's economic integrations, which provide opportunities for market expansion in a very wide area. An aim in itself is already the increase of competitiveness of the economy by increasing its exporting capacity to reduce the trade deficit Kosovo currently has. As an important location for business development Kosovo offers a range of comparative advantages such as: a young and very qualified population, where the average age is very young, natural resources, favorable climate conditions, new infrastructure, fiscal policy with the lowest taxes in the region, geographical location with access to the CEFTA and the European Union regional market. In addition to being a member of CEFTA, in June 2009 Kosovo has joined the IMF (International Monetary Fund) and WB (World Bank) and aspires to join other powerful economic and financial mechanisms such as World Trade Organization (WTO etc.). While taking into account Kosovo's rankings regarding the indicators that reflect the business environment one can conclude that a lot of progress has to be made in order to achieve the average rankings of the countries from Eastern Europe \& Central Asia as presented in the Report.

Especially, lots of effort has to be done in the fields of Protecting Investors (ranked 100), Enforcing Contracts (ranked 138) and Registering Property (ranked 76) as main (indirect) factors influencing the attitude of the domestic and foreign investors as well as the Banks operating in Kosovo when they determine their respective interest rates on loans for both corporate and household sector.

In this manner, the overall "environment for doing business", the rule of law and the enforcement of contracts in a timely and cost efficient manner represent an input in the forming of the interest rates calculation. Therefore, 
the connection between the rankings of the economy and the overall interest rates on its market are inversely proportional - the higher the rating of the economy the lower tend to be the average interest rates offered by Banks in the economy and the higher probability for foreign investments.

In 2011, minimum wages for employees of the public and private sector was set at EUR 170 per month ${ }^{1}$. Currently average monthly wage is said to be in the range of EUR 220 to 250 for civil servants and about EUR 300 at private enterprises ${ }^{2}$.

Kosovo fits in the general investment patterns of international business in the region. Most attractive industries have been the telecommunication industry, the energy sector, extraction of raw materials, and the banking sector. Among the first to attract international investors was the banking sector.

The region as a whole has not used its complete potential to attract investors. In the beginning of transition the political instability and armed conflicts played an important role but after they have been solved the major reasons lie in the weak business environment.

In the case of Kosovo serious measures need to be introduced that would address its business environment. Special attention needs to be paid to the rule of law in terms of protecting investors, and Enforcing contracts (ranked 100 and 138 respectively) and in administrative procedures, where Registering Property it's ranked 78.

This becomes even more important due to the role these factors have for the determination of interest rates and the situation with financing business activities in Kosovo. Market and country premium influence the level of interest rates since they too determine the cost of collecting loans. In spite of several concerns about the lack of infrastructure, low skill level of the labor force, high level of corruption, and weak rule of law, Kosovo has economic potential being mainly based on a generally business-friendly attitude, its young population showing an entrepreneurial spirit as well as the availability of agrarian land and underground assets such as lignite (reserves rank fifth in the world), zinc, lead, gold, cadmium, bismuth, bauxite, nickel and other commodities. What makes this unfavorable business climate, especially for foreign investment, according to economic experts, is bureaucracy, excessive procedures for starting a business, and the rule of law.

Improving the business climate in Kosovo is an essential element for encouraging foreign investment. In global politics today is indisputable trend of globalization process, which as such is slow but surely dominated by developments within the world political dynamics for the purpose of potential marginalization as traditional forms of organization and management of life of citizens.

\section{References}

Bartlett W. \& Prica I.(2012) The variable impact of the global economic crisis in South East Europe.

Basu P., Chakraborty C., \& Reagle D., (2003) Liberalization, FDI, and Growth in Developing Countries: A Panel Co integration Approach, Economic Inquiry, Western Economic Association International, vol. 41(3), pP $510-516$

Central Bank of Kosovo (2012a) Time Series Q4/2012.

Doing Business Report (2013c) Economic Profile: Kosovo

Doing Business Report (2014c) Economic Profile: Kosovo

Hasani,Visoka Vjollca(2013), The Process Of the transition in Western Balkan with the influence on macroeconomic development in the region; International Scientific Journal Disscussion,3-4th ed - Center of International Relations and Balkan studies, Tetovo,FYROM.

Hasani,V.Vjollca(2012), Significance of globalization in economic development; Globalization and Development: Case of Kosovo- Thesis-International Research Review Volume Ist,AAB University, Prishtina,R.KS.

Institute for advanced studies GAP, Jeton Mehmeti, Entrepreneurship and occupations of the future in Kosovo. http://www.gapmonitor.org/?id=17\&n=23\&language=en

Republic of Kosovo, ministry of trade and industry, investing in Kosovo 2009.

World Bank, Doing Business 2014.

Based on a decision issued by the Ministry for Labor and Social Welfare of Kosovo

Based on estimation gathered by the State Statistical office in Kosovo

Program http://www.usaidyep.org/index.php?option=com_content\&view=article\&id=21:entrepreneurship-andoccupations-of-the-future-in-kosovo\&catid=8:entrepreneur-resources $\&$ Itemid $=4 \&$ lang=en)

\footnotetext{
${ }^{1}$ Based on a decision issued by the Ministry for Labor and Social Welfare of Kosovo

${ }^{2}$ Based on estimation gathered by the State Statistical office in Kosovo
} 